\title{
Seasonal variation of phytoplankton nutrient limitation in Lake Erie
}

\author{
Jessica B. Moon, Hunter J. Carrick* \\ School of Forest Resources, The Pennsylvania State University, University Park, Pennsylvania 16802, USA
}

\begin{abstract}
Phosphorus (P) has been identified as the primary nutrient limiting phytoplankton biomass in the Laurentian Great Lakes, and thus phytoplankton biomass varies as a function of P loading. While management efforts have reduced point sources of $\mathrm{P}$, a recent rise in non-point source loadings and the introduction of dreissenid mussels to the Great Lakes are factors suspected to have direct and indirect impacts on nutrient cycling. We re-evaluated nutrient limitation of phytoplankton in the central basin of Lake Erie over spatial (i.e. 3 offshore stations) and temporal (i.e. monthly from June to October) scales. The nutrient limitation of the phytoplankton was evaluated using biomass response measurements to nutrient enrichment bioassays in a complete factorial of $\mathrm{P}$, nitrogen $(\mathrm{N})$, and silicon ( $\mathrm{Si}$ ). Nutrient additions yielded classic growth curves after 7 to $12 \mathrm{~d}$ of incubation. Treatments with added $\mathrm{P}$ had higher final biomass yields than treatments without $\mathrm{P}$ at all stations and during all months. During spring overturn, P+Si yielded higher phytoplankton biomass than did P additions without $\mathrm{Si}$ at 2 of the 3 stations. During the late stratification to autumn overturn (August to October), $\mathrm{P}+\mathrm{N}$ promoted higher phytoplankton biomass than did $\mathrm{P}$ additions without $\mathrm{N}_{i}$ this was true at all stations. A quantitative assessment of the bioassays indicated that 63 to $94 \%$ of the biomass yield during spring overturn could be attributed to $\mathrm{Si}$, while 48 to $68 \%$ of the biomass yield during late stratification and autumn overturn could be attributed to N. Water chemistry data collected in 2002 and 2003 predicted similar seasonal trends in nutrient limitation. These results suggest that seasonal variation in phytoplankton nutrient limitation is a probable factor in predicting changes in phytoplankton biomass and taxonomic composition in the central basin of Lake Erie.
\end{abstract}

KEY WORDS: Phytoplankton · Lake Erie $\cdot$ Nutrient status

\section{INTRODUCTION}

Several key nutrients limit plant growth in both terrestrial and aquatic ecosystems (Sterner \& Elser 2002). In many temperate freshwater lakes, phosphorus (P) has been identified as the primary nutrient limiting phytoplankton biomass (Schindler 1977), although other nutrients (e.g. nitrogen [N] and silicon [Si]) have also been identified as limiting and may reflect accelerated eutrophication (e.g. Schelske et al. 1978, Murphy 1980). In Lake Erie, ongoing management efforts have reduced $\mathrm{P}$ inputs from phosphate-based detergents and sewage treatment plants below the 11000 ton $\mathrm{yr}^{-1}$ target (Dolan 1993), with an associated decline in phytoplankton biomass (e.g. Makarewicz \& Bertram 1991). However, recent survey data indicate that total phosphorus (TP) is on the rise in Lake Erie (e.g. 1995 to present: Rockwell \& Warren 2003), some of which may be tied to an increase in non-point source loadings of P since the early 1990s (Dolan et al. 2004). Moreover, the introduction of non-native dreissenid mussels to the Great Lakes in the mid-1980s appears to have altered N:P ratios (e.g. Nalepa \& Fahnenstiel 1995), through their direct (grazing) and indirect (excretion) effects on nutrient cycling (Heath et al. 1995, Vanderploeg et al. 2001).

Shifts in nutrient concentrations and ratios can alter both the composition and the biomass of the phytoplankton assemblage (e.g. Tilman 1982). Thus, reevaluating the current role of $\mathrm{P}$ in controlling phytoplankton biomass and composition is becoming increasingly important in Lake Erie (Carrick 2004). In addition, understanding seasonal and spatial variation in phytoplankton nutrient limitation continues to be 
important for effective management initiatives, an area of research where effort has been limited in the past (Elser et al. 1990). Moreover, the Great Lakes Fisheries Commission (GLFC) recognizes that, since the enactment of TP controls and the introduction of non-native dreissenids, many of the changes at the lower trophic levels appear to have influenced both the composition and productivity of the fish communities in the lake, yet little is known about the response at lower trophic levels (GLFC 1998).

Nutrient enrichment bioassays have been widely used to evaluate nutrient limitations of phytoplankton (Lin \& Schelske 1981). Therefore, we implemented $2 \times$ 3 factorial nutrient enrichment bioassays (NEB) experiments using natural phytoplankton assemblages from Lake Erie to achieve 3 objectives. First, we evaluated the main and interactive effects of $\mathrm{P}, \mathrm{N}$, and $\mathrm{Si}$ in regulating phytoplankton biomass. Second, we characterized the seasonal and spatial variation of phytoplankton nutrient limitation by performing bioassays across 3 thermal periods (spring overturn, stratification, and autumn overturn) at 3 offshore stations in the central basin. Third, we estimated the contribution of individual nutrients to bioassay biomass yields in order to speculate the relative importance of each nutrient to the phytoplankton assemblage during the 3 thermal periods.

\section{MATERIALS AND METHODS}

Field sampling. Water was routinely collected from 10 offshore stations in the central basin of Lake Erie (mean depth $19.5 \mathrm{~m}$, volume $483 \mathrm{~km}^{3}$, Fig. 1), which holds most of the lake's volume (Beeton 1960). Sampling was conducted aboard the RV 'Lake Guardian' and the RV 'Limnos' between June and October in both 2002 and 2003. During each cruise, water was col-

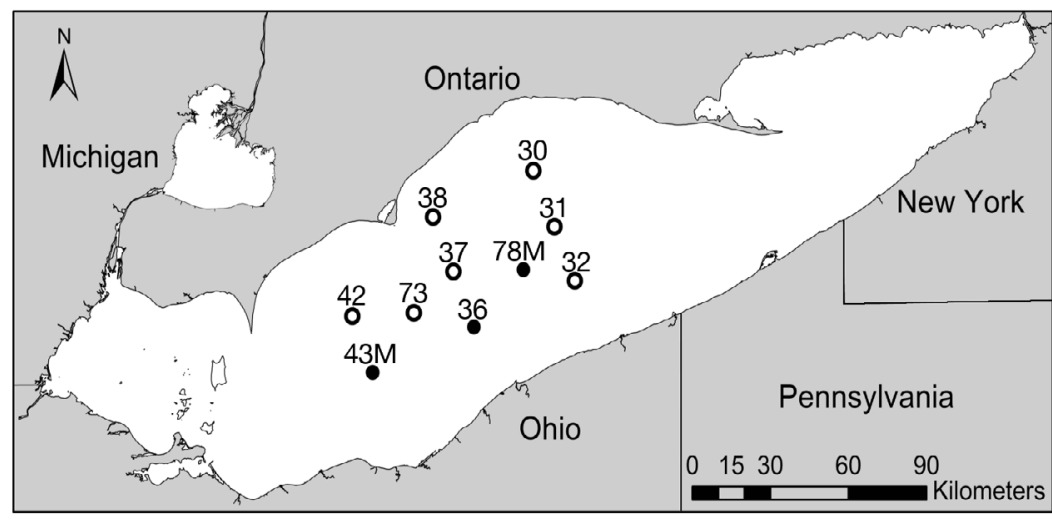

Fig. 1. Lake Erie, indicating the 10 EPA-established water chemical sampling sites for 2002 and 2003 in the central basin. •: phytoplankton composition, chl $a$, and bioassay sampling locations lected for chemical and biological analyses, using 81 Niskin bottles mounted on a General Oceanics Rossette Sampler. A Seabird CTD profiler (SBE-19) attached to the bottom of the Rossette was used to record high resolution depth profiles of dissolved oxygen (DO), temperature, photosynthetically available radiation (PAR), and chlorophyll fluorescence.

The data presented here include phytoplankton species composition, chemical concentrations, and NEB experimental results. Phytoplankton species composition was measured using water samples taken on 4 dates (18 June, 17 July, 17 August, 14 September) in 2002 at Stn $78 \mathrm{M}$ at mid-epilimnion depth (Fig. 1). Chemical analyses ( $\mathrm{Si}, \mathrm{N}$, and $\mathrm{P}$ ) were performed on water samples (2 to 3 depths in the epilimnion) that were collected on 7 dates in both 2002 and 2003 from all 10 offshore stations in the central basin (see Table 2 , Fig. 1). Finally, monthly water samples were collected to measure phytoplankton nutrient status using NEB experiments on 5 dates in 2003 (6 June, 23 July, 19 August, 15 September, 1 October). These water samples were collected at the mean depth of the mixed epilimnion (5 to $10 \mathrm{~m}$ ) from 3 stations in the central basin (43M, 36, and 78M; Fig. 1).

Phytoplankton cell counts. Water for phytoplankton species composition was preserved with $1 \%$ Lugol's solution for microplankton (20 to $200 \mu \mathrm{m}$ ) and $1 \%$ glutaraldehyde for nanoplankton (2 to $20 \mu \mathrm{m}$; Carrick \& Schelske 1997). Duplicate nanoplankton slides were made within $1 \mathrm{~d}$ of collection by filtering 10 to $20 \mathrm{ml}$ of preserved sample onto darkened filters $(0.8 \mu \mathrm{m}$, Nucleopore). Filters were stained with primulin and stored at $-20^{\circ} \mathrm{C}$ (Caron 1983). Nanoplankton were counted by epifluorescence microscopy using a Leica DMR research microscope. In total, 500 individuals were counted from randomly chosen microscope fields at $1000 \times$ magnification. Microplankton slides were prepared by filtering 10 to $20 \mathrm{ml}$ of sample onto membranes (3.0 pore, Millipore filters; see Dozier \& Richerson 1975). Filters were cleared (using glutaraldehyde) and mounted on oversized slides with Permount. Microplankton were counted at $400 \times$ using phase contrast microscopy.

All phytoplankton taxa were identified using several literature sources, including Prescott (1973), Whitford \& Schumacher (1973), and Rippka et al. (1979) (specifically for cyanobacteria). Diatoms were identified using Patrick \& Reimer (1966, 1975) and Krammer \& Lange-Bertalot (1991). The cell dimensions of 10 randomly chosen individuals from each taxon 
were measured. Dimensions were fit to geometric shapes that most accurately described the shape of the taxon. Cell volume was estimated and converted to carbon using the equations of Strathmann (1967) for all diatoms and the biovolume-carbon relationship for non-diatoms, nano-, and micro-algae of Verity et al. (1992).

Ambient water chemistry. Lake water for all physiochemical constituents was placed in acid-cleaned plastic containers with polypropylene caps. Total phosphorus (TP as $\mathrm{P} \mu \mathrm{g} \mathrm{l}^{-1}$ ), dissolved phosphorus (DP as $\mathrm{P} \mu \mathrm{g}$ $\left.\mathrm{l}^{-1}\right)$, nitrate-nitrite $\left(\mathrm{NO}_{3}-\mathrm{NO}_{2}\right.$ as $\left.\mathrm{N} \mu \mathrm{l}^{-1}\right)$ and dissolved reactive silica $\left(\mathrm{SiO}_{2}\right.$ as $\left.\mathrm{Si} \mu \mathrm{g} \mathrm{l}^{-1}\right)$ concentrations were determined from standard colorimetric reactions using a Technicon Autoanalyzer following Environmental Protection Agency analytical procedures (EPA 2003). Standard curves and blanks were run to ensure that acceptable QA/QC conditions were met.

Nutrient enrichment bioassays. Bioassays were initiated by placing lake water in acid-washed 101 carboys that were wrapped in black plastic bags to prevent light shocking. The carboys were kept in the black plastic bags or covered with screening for the duration of the cruise and were kept at ambient lake conditions in a temperature-controlled room (June), or in a shipboard incubator (July, August, and September). Coolers were transported to the laboratory in University Park, Pennsylvania, within $24 \mathrm{~h}$ of collection, except during the July cruise when travel required a $79 \mathrm{~h}$ transport period.

Bioassays were used to evaluate nutrient limitation of phytoplankton assemblages collected from the central basin (Schelske 1984). Bioassays were performed much like batch culture experiments (Schelske 1984), where 8 nutrient treatments (including the control) were added to lake water in 1 dose (in duplicate) at the beginning of each experiment. Briefly, lake water was screened through a plankton net $(105 \mu \mathrm{m})$ before treatment to minimize predation by zooplankton. This net size did not completely eliminate all important predators (e.g. microzooplankton; see Carrick \& Fahnenstiel 1989), but it was likely to be effective in retaining a large portion of the phytoplankton community while removing larger invertebrate predators that are key grazers on phytoplankton (Scavia \& Fahnenstiel 1987). Next, $400 \mathrm{ml}$ aliquots of the screened lake water were dispensed into $500 \mathrm{ml}$ polycarbonate Erlenmeyer flasks. The nutrient enrichments were carried out using a $2 \times 3$ factorial design of $\mathrm{P}\left(\mathrm{NaH}_{2} \mathrm{PO}_{4} \cdot \mathrm{H}_{2} \mathrm{O}\right.$, Mallinckrodt 7868), $\mathrm{N}\left(\mathrm{NaNO}_{3}\right.$, Fisher Scientific S343), and $\mathrm{Si}\left(\mathrm{Na}_{2} \mathrm{SiO}_{3} \cdot 9 \mathrm{H}_{2} \mathrm{O}\right.$, J. T. Baker 3868-01). Nutrient enrichments were added at concentrations of

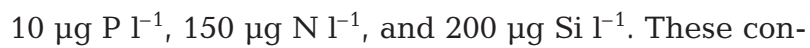
centrations approximately doubled the levels of nutrients that were measured in the ambient lake water.
Table 1. Experimental conditions for nutrient enrichment bioassay experiments conducted with water collected monthly from the mid-eplimnion or mid-water column depth at 3 stations (Stns 36, 43M and 78M) from June through October 2003

\begin{tabular}{|c|c|c|c|}
\hline Month & $\begin{array}{l}\text { Sunrise } \\
\text { Sunset }^{\mathrm{a}}\end{array}$ & $\begin{array}{c}\text { Laboratory } \\
\text { Day:Night (h:h) }\end{array}$ & $\begin{array}{c}\text { Laboratory } \\
\text { incubator }\left({ }^{\circ} \mathrm{C}\right)^{\mathrm{b}}\end{array}$ \\
\hline Jun & $\begin{array}{l}05: 54 \\
20: 55\end{array}$ & $15: 9$ & 10.5 \\
\hline Jul & $\begin{array}{l}06: 11 \\
20: 54\end{array}$ & $15: 9$ & 21.0 \\
\hline Aug & $\begin{array}{l}06: 39 \\
20: 22\end{array}$ & $14: 10$ & 23.5 \\
\hline Sep & $\begin{array}{l}07: 06 \\
19: 38\end{array}$ & $12.5: 11.5$ & 23.5 \\
\hline Oct & $\begin{array}{l}07: 22 \\
19: 10\end{array}$ & $11.5: 12.5$ & 19.2 \\
\hline \multicolumn{4}{|c|}{$\begin{array}{l}\text { a Taken from Cleveland, Ohio: www.sunrisesunset.com, } \\
\text { last accessed } 13 \text { August } 2005 \\
\text { b Incubator temperature was set at the average ambient } \\
\text { temperature of the mid-eplimnion (July, August, Septem- } \\
\text { ber) or water column mixed depth (June, October) }\end{array}$} \\
\hline
\end{tabular}

All experimental bottles were incubated $(n=16)$ in an I36HID incubator (Percival Scientific). Conditions in the incubator were set at day:night light cycles and temperatures comparable to the natural seasonal variation (Table 1). Light intensity was set between 400 and $500 \mu \mathrm{E} \mathrm{m} \mathrm{m}^{-2} \mathrm{~s}^{-1}$, which is above the threshold where maximum primary productivity generally occurs for Great Lakes phytoplankton (Fahnenstiel et al. 1989). Bottles were randomized daily, shaken by hand 3 times (to minimize settling on the bottom), and rotated together (by station) to minimize unevenness in the light received inside the incubator.

In all experiments, bottles were sampled every $24 \mathrm{~h}$ to measure in vivo chlorophyll a ( $\mathrm{chl} \mathrm{a)} \mathrm{fluorescence.}$ Eight ml of water were removed from each bottle and placed in cuvettes at approximately the same time each day. The total volume removed was $<20 \%$ of the total volume, so we assumed the decrease in volume had little influence on the outcome of these experiments. Once collected, samples were allowed to adapt to darkness for $20 \mathrm{~min}$ and were then read on a Turner Designs 10-AU fluorometer (Vincent 1979). Experiments ran until maximum biomass yields were achieved for each treatment. Experiments were terminated when in vivo measurements reached constant values, indicating no further increase in phytoplankton biomass.

At the beginning and termination of each experiment, duplicate sub-samples $(50 \mathrm{ml})$ from each bottle were concentrated onto membranes $(0.3 \mu \mathrm{m}$ filters, Whatman EPM 2000) to estimate chl a concentrations. Chl a was extracted using the $90 \%$ acetone-DMSO 
(50:50) extraction procedure (Shoaf \& Lium 1976) without grinding (Carrick et al. 1993). Chl a and phaeophyton were measured using a Turner Designs 10-AU fluorometer, and final chl a concentrations were corrected for phaeophyton.

Statistical analysis. Maximum algal biomass, measured as maximum in vivo fluorescence, in the experimental bottles was analyzed using a 3-way analysis of variance (ANOVA), where nutrient treatments, stations, and dates were considered fixed factors. Given that the 3-way ANOVA yielded significant interaction terms (see Table 3), 1-way ANOVAs were used to test for differences among nutrient treatments by blocking the analysis by station and by date. Normality and homogeneity of variance were achieved by transforming in vivo maximum yield (i.e. $\ln [\max$ yield]), and Tukey's post-hoc tests were used to test for pairwise differences among fixed factors. Transformed final extracted chl a measures (i.e. ln [final yield]) were analyzed in a similar manner for comparison.

The quantitative biomass yield that could be attributed to the influence of single nutrients ( $\mathrm{Si}, \mathrm{N}$, and $\mathrm{P}$ ) was deduced (and calculated) from the results achieved through the factorial enrichment experiments. The net biomass yield was determined by subtracting the initial from the maximum in vivo fluorescent yield of treatments $\mathrm{P}, \mathrm{P}+\mathrm{Si}, \mathrm{P}+\mathrm{N}$, and $\mathrm{P}+\mathrm{N}+\mathrm{Si}$ (or control treatments were used in experiments where photo-acclimation occurred during the 0 to $24 \mathrm{~h}$ period of incubation; see Carrick et al. 1993). The contribution of $\mathrm{P}$ to biomass yield was assumed to be equivalent to the biomass yield in the $\mathrm{P}$ treatment. The secondary contribution of $\mathrm{N}$ and $\mathrm{Si}$ to biomass yield was determined by subtracting either $\mathrm{P}+\mathrm{N}$ treatment or $\mathrm{P}+\mathrm{Si}$ treatment from the $\mathrm{P}$ treatment, depending on which was greater than the P treatment.

The predictive validity of in vivo fluorescence for estimating biomass was determined by comparing in vivo fluorescence to measurements of extracted chl $a$, a commonly used proxy of biomass (Wetzel \& Likens 2000). Linear regression of in vivo fluorescence onto extracted chl a produced a significant linear relationship: $\ln ($ extracted chl $a+1)=\{2.01 \times[\ln ($ in vivo +1$)]\}+$ 0.637 . These results indicate that the 2 methods were comparable $\left(\mathrm{r}^{2}=0.71, \mathrm{n}=403, \mathrm{p}<0.001\right)$. SPSS statistical software was used for all statistical analyses and $\alpha$ significance levels were set at 0.05 .

\section{RESULTS}

\section{Ambient lake conditions}

Thermal periods of spring overturn, stratification, and autumn overturn varied between the 2002 and
2003 cruises. During 2002, the central basin was thermally stratified during June, July, and August sampling periods, but underwent isothermal mixing during the September sampling. In contrast, in 2003, the end of spring overturn (i.e. initial stratification) occurred during the June cruise, and stratification occurred during July, August, and September cruises when the thermocline ranged between 16 and $22 \mathrm{~m}$. Autumn overturn did not occur until the October cruise.

The biomass and taxonomic composition of surface assemblages varied among sampling dates, with total algal carbon content ranging between $49.5 \mu \mathrm{g} \mathrm{C}^{-1}$ in June and 88.2 $\mu \mathrm{g} \mathrm{C}^{-1}$ in July (Fig. 2). In June, algal carbon content was dominated by cryptophytes (mostly Cryptomonas erosa Ehrend.), with diatoms (Bacillariophyta) being subdominant (namely Cyclotella comensis Grun.). The phytoplankton assemblage in July was dominated by the chrysophyte Ophiocytium cochleare (Eichw.) A. Braun and to a lesser degree by cryptophytes (mainly Rhodomonas minuta Skuja). By August, the assemblage exhibited its greatest relative diversity, where all 6 divisions of phytoplankton were observed. At this time, the assemblage was composed of pyrrophytes (e.g. Ceratium hirudinella), cryptophytes (Rhodomonas spp.), and to a lesser extent cyanobacteria (e.g. Anabaena circinalis Rabenhorst). During the autumn overturn in September, the assemblage was similar to that observed in August, although a shift in dominant taxa was noted (Cryptophyta: Cryptomonas erosa Ehrend., Chrysophyta: Chrysochromulina parva Lackey, Chrysosphaerella longispina Lauterborn, and cyanobacteria: Anabaena circinalis Rabenhorst, Microcystis sp.).

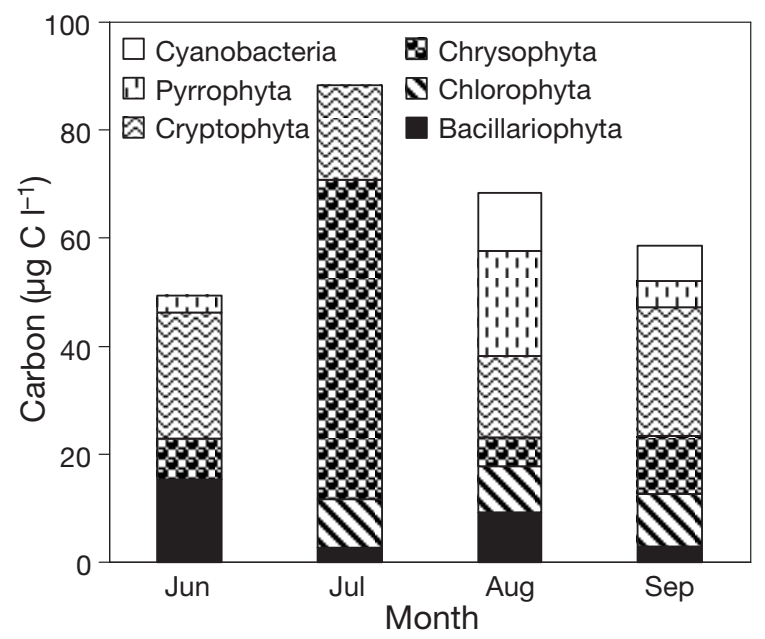

Fig. 2. Phytoplankton community composition and biomass for ambient water collected from the mid-epilimnion or midwater column depth at Stn 78M (not including phototrophic picoplankton counts), from June through September 2002 


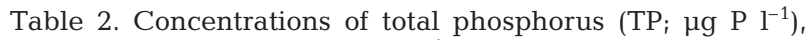
nitrate-nitrite $\left(\mathrm{NO}_{3}-\mathrm{NO}_{2} ; \mu \mathrm{g} \mathrm{N} \mathrm{l}{ }^{-1}\right)$, and dissolved reactive silica $\left(\mu \mathrm{g} \mathrm{Si}^{-1}\right)$ as means \pm SD during 7 water sampling events in 2002 and 2003. Means and SD were calculated by averaging nutrient concentrations across 3 depths at 10 offshore EPA stations in the central basin of Lake Erie in 2002 and across 2 depths of the same 10 off shore stations in 2003

\begin{tabular}{|lccc|}
\hline Date & $\mathrm{TP}$ & $\mathrm{NO}_{3}-\mathrm{NO}_{2}$ & $\begin{array}{c}\text { Dissolved } \\
\text { reactive } \mathrm{SiO}_{2}\end{array}$ \\
\hline 2002 & & & \\
6 Jun & $5.6 \pm 1.2$ & $198.3 \pm 126.6$ & $198.9 \pm 128.5$ \\
18 Jun & $5.3 \pm 1.1$ & $195.2 \pm 96.1$ & $158.6 \pm 88.6$ \\
25 Jun & $4.8 \pm 1.7$ & $168.9 \pm 96.5$ & $112.4 \pm 39.9$ \\
17 Jul & $5.2 \pm 0.9$ & $196.9 \pm 69.7$ & $166.1 \pm 68.6$ \\
6 Aug & $5.4 \pm 0.9$ & $204.3 \pm 50.1$ & $107.2 \pm 130.7$ \\
17 Aug & $6.8 \pm 2.3$ & $203.8 \pm 21.3$ & $197.8 \pm 249.7$ \\
14 Sep & $10.5 \pm 2.5$ & $150.7 \pm 23.0$ & $345.9 \pm 243.4$ \\
Average & 6.2 & 188.3 & 183.8 \\
SD & \pm 2.0 & \pm 20.4 & \pm 80.2 \\
2003 & & & \\
5 Jun & $8.5 \pm 1.9$ & $199.1 \pm 108.5$ & $97.5 \pm 25.5$ \\
19 Jun & $6.4 \pm 2.1$ & $217.5 \pm 118.8$ & $130.8 \pm 77.0$ \\
27 Jun & $4.3 \pm 1.1$ & $196.5 \pm 70.0$ & $207.7 \pm 65.0$ \\
18 Jul & $6.2 \pm 1.3$ & $195.4 \pm 73.3$ & $181.8 \pm 24.1$ \\
19 Aug & $8.4 \pm 2.8$ & $190.8 \pm 80.5$ & $283.3 \pm 268.8$ \\
Sep & $9.6 \pm 2.3$ & $174.0 \pm 62.1$ & $423.1 \pm 384.7$ \\
Sep & $10.6 \pm 7.8$ & $152.5 \pm 66.9$ & $273.4 \pm 344.0$ \\
Average & 7.7 & 189.4 & 228.2 \\
SD & \pm 2.2 & \pm 20.7 & \pm 109.7 \\
& & & \\
\hline
\end{tabular}

Ambient nutrient concentrations exhibited seasonal variability, although the patterns were consistent between years (2002 and 2003, Table 2). TP concentrations were relatively constant during the stratified period, and were 2-fold greater in the spring and autumn overturn periods. $\mathrm{NO}_{3}-\mathrm{NO}_{2}$ concentrations were also relatively consistent from early June to late August; however, levels decreased by more than $50 \mu \mathrm{g}$ $\mathrm{N}^{-1}$ by September. This led to a 2 -fold decline in the $\mathrm{NO}_{3}-\mathrm{NO}_{2}$ :TP molar ratio (80:1 vs. 30:1). Dissolved reactive $\mathrm{SiO}_{2}$ concentrations were variable, but generally showed an increase during the autumn overturn period in both years.

\section{Bioassay experiments}

The maximum and final biomass yield 3-way ANOVAs showed significant differences among all 3 factors (nutrient treatment, station, and date) and among all interactions (Table 3). Maximum biomass in the experimental bottles was observed between 7 and $11 \mathrm{~d}$ of incubation. The change over time in the bottles was predictable and resembled that described by a logistic growth curve. Overall, these experiments appear to be of an appropriate time scale to evaluate growth-related changes in phytoplankton population size (see Carrick et al. 1993).

Given the results from 3-way ANOVAs, a series of 1-way ANOVAs was performed to evaluate the combination of nutrients that might limit phytoplankton growth among stations and dates. These analyses showed that in 12 of 15 experiments, P was the primary limiting nutrient (Table 4, Fig. 3). In the July, August, September, and October experiments, all treatments with P supported higher biomass ( $p>0.001)$ than treatments without $\mathrm{P}$ (Table 4, Fig. 3). In June, $\mathrm{P}$ also yielded higher biomass, although this pattern was only significant when final extract chl a values were used in

Table 3. Results from 3-way ANOVAs, assessing the variation in maximum in vivo chl a fluorescence with nutrient treatments, dates, and stations set as fixed factors

\begin{tabular}{|lrrr|}
\hline Source & F-statistic & df & p-value \\
\hline Treatment & 593.9 & 7 & $<0.001$ \\
Date & 1557.6 & 4 & $<0.001$ \\
Station & 170.5 & 2 & $<0.001$ \\
Treatment $\times$ Date & 43.9 & 28 & $<0.001$ \\
Treatment $\times$ Station & 2.8 & 14 & 0.001 \\
Date $\times$ Station & 113.7 & 8 & $<0.001$ \\
Treatment $\times$ Date $\times$ Station & 4.2 & 56 & $<0.001$ \\
\hline
\end{tabular}

Table 4. Results from 1-way ANOVAs, assessing the variation in maximum in vivo chl a fluorescence among nutrient treatments. Treatments joined by underlining them were not significantly different from one another when assessed with Tukey pairwise comparisons, where mean fluorescence values for each treatment were ordered from lowest to highest. C: control

\begin{tabular}{|c|c|c|c|c|}
\hline Mo & Stn & $\begin{array}{c}F- \\
\text { statistic }\end{array}$ & $\begin{array}{c}\mathrm{p}- \\
\text { value }\end{array}$ & 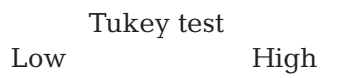 \\
\hline \multirow[t]{3}{*}{ Jun } & 43 & 9.4 & 0.003 & $\underline{\text { N C P NSi PN Si PSi PNSi }}$ \\
\hline & 36 & 78.7 & $<0.001$ & $\underline{\mathrm{C} N \mathrm{NSi}} \underline{\mathrm{Si} P \text { PN }} \underline{\mathrm{PNSi}} \mathrm{PSi}$ \\
\hline & 78 & 4.9 & 0.021 & NSi N Si C P PSi PNSi PN \\
\hline \multirow[t]{3}{*}{ Jul } & 43 & 18.3 & $<0.001$ & N NSi C Si PN P PSi PNSi \\
\hline & 36 & 109.1 & $<0.001$ & NSi N C Si P PN PSi PNSi \\
\hline & 78 & 27.1 & $<0.001$ & Si N NSi C P PNSi PN PSi \\
\hline \multirow[t]{3}{*}{ Aug } & 43 & 355.8 & $<0.001$ & NSi Si C N PNSi PSi PN P \\
\hline & 36 & 685.0 & $<0.001$ & $\overline{\text { NSi C N Si }} \overline{\text { P PSi PNSi PN }}$ \\
\hline & 78 & 693.2 & $<0.001$ & $\overline{\text { Si N NSi C }}$ P PSi PNSi PN \\
\hline \multirow[t]{3}{*}{ Sep } & 43 & 62.9 & $<0.001$ & NSi Si N C PSi PNSi P PN \\
\hline & 36 & 20.1 & $<0.001$ & $\overline{\mathrm{N} C \mathrm{Si} N \mathrm{Ni}} \overline{\mathrm{PN} \text { PSi P PNSi }}$ \\
\hline & 78 & 241.3 & $<0.001$ & C NSi N Si P PSi PN PNSi \\
\hline \multirow[t]{3}{*}{ Oct } & 43 & 34.9 & $<0.001$ & Si C NSi N PSi P PN PNSi \\
\hline & 36 & 107.1 & $<0.001$ & C NSi Si N P PSi PNSi PN \\
\hline & 78 & 67.1 & $<0.001$ & NSi N C Si P PSi PNSi PN \\
\hline
\end{tabular}


the comparison in lieu of in vivo fluorescence measurements.

Si additions alone did not stimulate phytoplankton growth during bioassay experiments $(p>0.05)$; however, $\mathrm{P}+\mathrm{Si}$ did lead to greater growth relative to $\mathrm{P}$ additions without Si during spring turnover (Table 4, Fig. 3).
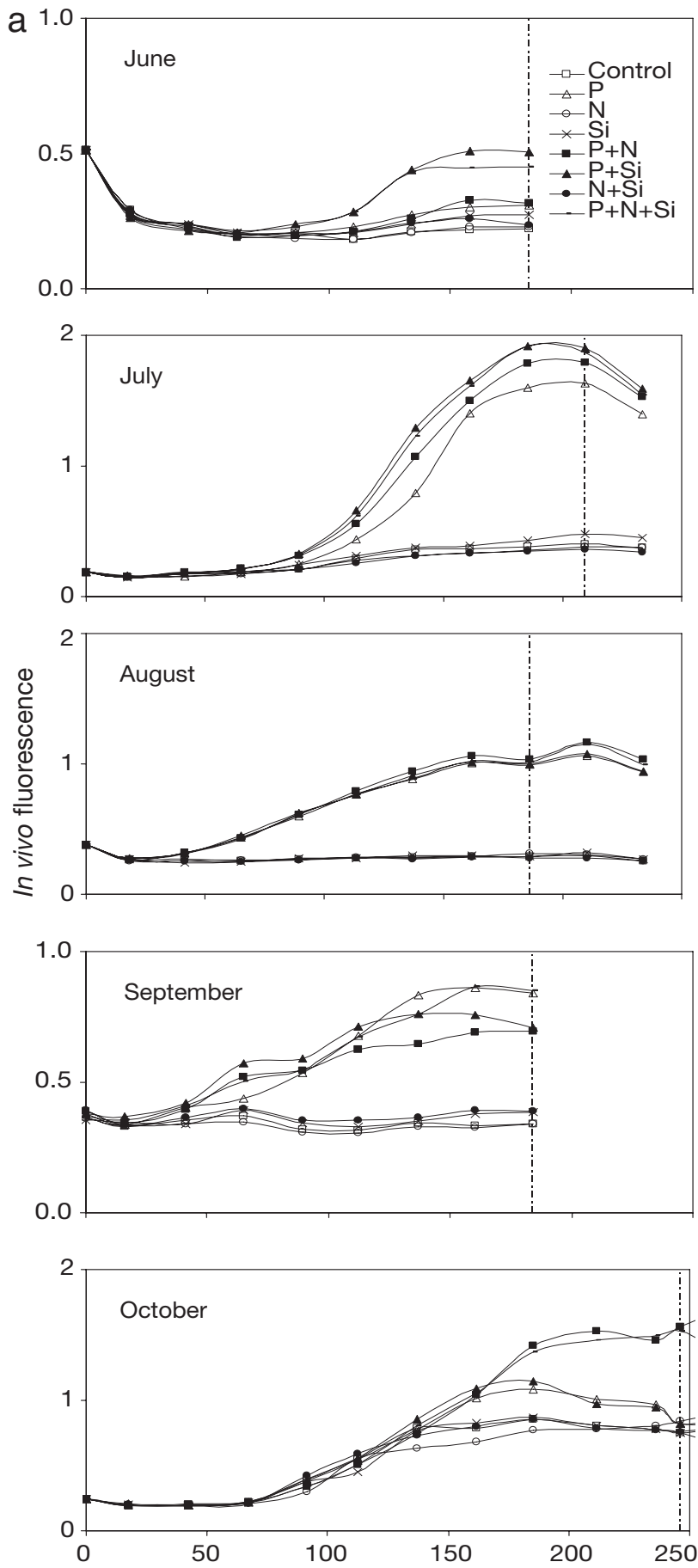

More specifically, in June, $\mathrm{P}+\mathrm{Si}$ enhanced biomass at Stns 43M and 36 (Table 4, Fig. 3). Although P+Si did not statistically differ from $\mathrm{P}$ treatments without $\mathrm{Si}$ at Stn $78 \mathrm{M}$, the final extracted chl $a$ values did reveal that treatments with both $\mathrm{P}$ and $\mathrm{Si}$ were higher than all other treatments. The increase in biomass found at all 3
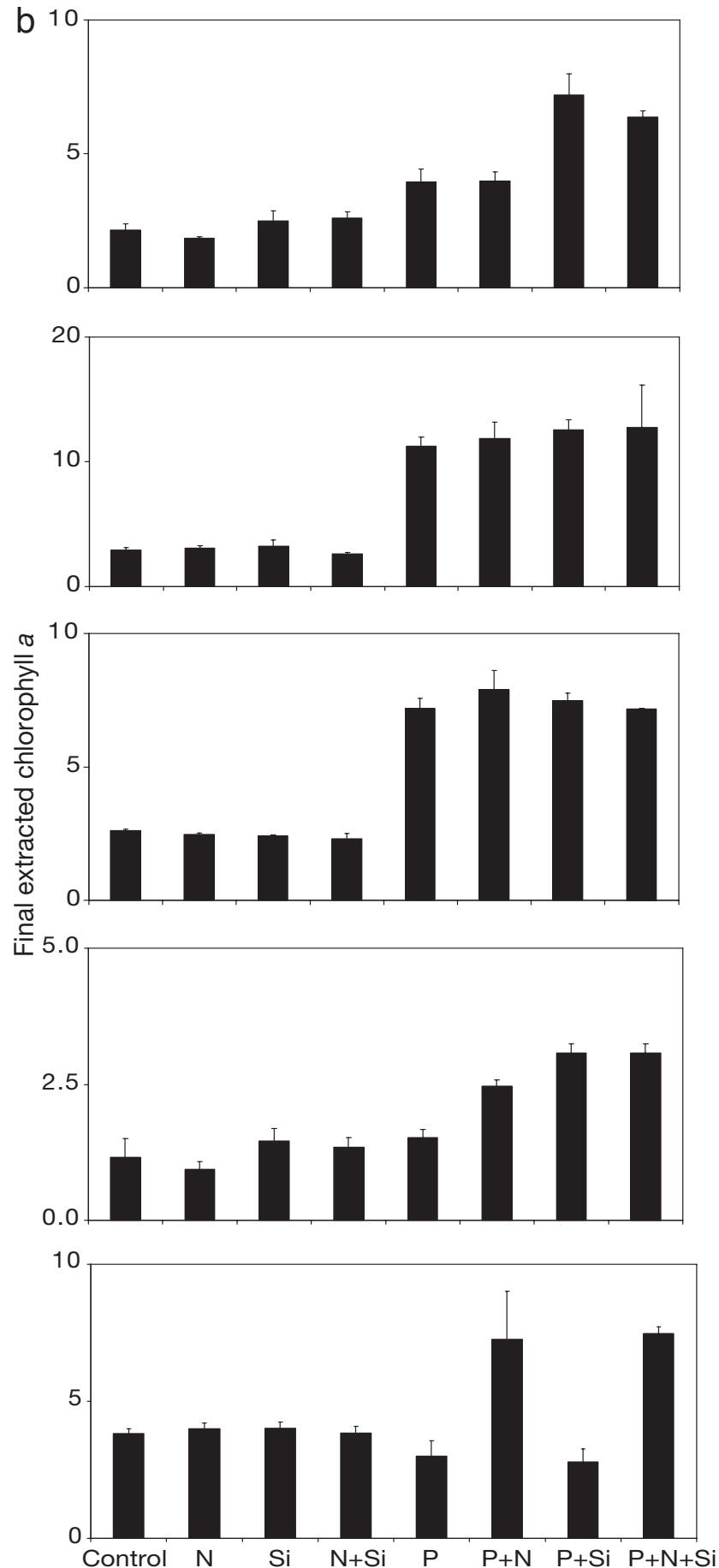

Fig. 3. (a) Time course of phytoplankton biomass from nutrient enrichment bioassays conducted at Stn 36 from June through October 2003. Average biomass (as in vivo fluorescence) values were derived from duplicate bottles receiving 1 of 8 treatments (control, P, N, Si, P+N, P+Si, N+Si, P+N+Si). Dotted vertical lines indicate final extracted chl a measurements. (b) Corresponding average final extracted chl a measurements for each duplicate bottle treatment. Error bars indicate SD 
stations was not an immediate response of the phytoplankton to the Si addition, but rather a secondary response. Thus, these nutrients appear to interact in a synergistic rather than an additive manner. During September and October, phytoplankton growth became evident after 5 to $7 \mathrm{~d}$ of incubation in treatments of $\mathrm{P}+\mathrm{Si}$ (Fig. 3); however, these biomass enhancements were not statistically different from enhancements found in treatments of $\mathrm{P}$ without $\mathrm{Si}$ (Table 4). This suggests that $\mathrm{P}$ was the nutrient that stimulated an enhancement of the phytoplankton biomass during these 2 months, not $\mathrm{Si}$.

Similarly, N additions alone did not stimulate phytoplankton growth during bioassay experiments, although $\mathrm{P}+\mathrm{N}$ in the late summer and fall promoted secondary growth relative to $\mathrm{P}$ additions without $\mathrm{N}$ (Table 4, Fig. 3). In August (Stn 78M), September (Stns 43M and 78M), and October (Stns 36 and $78 \mathrm{M}$ ) additions of $\mathrm{P}+\mathrm{N}$ produced a higher biomass yield than $P$ treatments without $\mathrm{N}$. At the third station in October $(43 \mathrm{M}), \mathrm{N}$ also yielded higher biomass, although this pattern was only significant when extracted chl a values were used in the comparison.

\section{DISCUSSION}

\section{Phytoplankton-phosphorus dynamics in Lake Erie}

Our bioassays clearly indicate that $P$ remains the primary limiting nutrient of phytoplankton biomass in Lake Erie, independent of time-space considerations in the lake (offshore station location or season). This finding is consistent with previous evaluations of nutrient status in Lake Erie that were based on phosphate turnover rate measurements (Lean et al. 1983, Allen \& Smith 2002, Guildford et al. 2005) and bioassay experiments (e.g. Hartig \& Wallen 1984, Twiss et al. 2000). These results are important, because they indicate, along with several other recent studies (Wilhelm et al. 2003, Guildford et al. 2005), that Lake Erie phytoplankton is P-limited despite the many changes in nutrient cycling that have occurred in the lake over the past 20 yr. For instance, municipal point sources of $P$ (annual) have been reduced several-fold since 1980 (Dolan 1993), and invasive dreissenid mussels (zebra mussel Dreissena polymorpha and quagga mussel $D$. bugensis) appear to have had direct (Holland 1993, Nichols et al. 1999) and indirect (Heath et al. 1995, Arnott \& Vanni 1996) impacts on P cycling.

The activity of planktivores can alter nutrient supply rates to the phytoplankton, thereby influencing their nutrient status (Vanni 1995). In the case of Lake Erie, dreissenid mussels (both zebra and quagga mussels) have colonized a considerable portion of the lake bot- tom $(\sim 70 \%)$, including both hard and soft substrata (Dermott \& Munawar 1993, Haltuch et al. 2000). Although currently there are no estimates of filtering impacts by dreissenid mussels in the central basin, estimates by MacIsaac et al. (1992) suggest that the mussels could filter 14 times the volume of the western basin in just $1 \mathrm{~d}$. With this in mind, it is likely that dreissenids have increased the rate of $P$ recycling back into the water column by filtering planktonic materials and excreting nutrients (Nichols et al. 1999) that would otherwise be lost to benthic sediment. This dynamic along with continuous low natural and anthropogenic inputs may account for the recent rise in TP concentrations in the water column of Lake Erie, which has not been associated with a comparable increase in chl a (Makarewicz at el. 1999, Charlton 2001). The decoupling between TP and chl a has also been observed in nearshore areas of Lakes Huron and Ontario, which have also been colonized by dreissenids (Nichols et al. 1999). These nearshore stations may retain large amounts of $\mathrm{P}$, consequently contributing to post-dreissenid symptoms of nearshore eutrophication (Hecky et al. 2004).

\section{Seasonal variation in phytoplankton nutrient status}

Perhaps our most important finding is that modest enrichment with $\mathrm{P}$ promoted time-dependent, secondary limitation by Si and N. This factor may be useful in deciphering seasonal phytoplankton dynamics, because the cycling of each nutrient varies seasonally in the Great Lakes (e.g. Laird et al. 1988), which in turn can influence the growth of specific phytoplankton populations (Hecky \& Kilham 1988). While there is a historical record of seasonal chl $a$ and nutrient chemistry for Lake Erie (Charlton 1999), there is limited current work characterizing the seasonal dynamics of nutrient limitation in Lake Erie (Guildford et al. 2005). To our knowledge, all but two of the pre-dreissenid studies (Lean et al. 1983, Hartig \& Wallen 1984) and all but two of the post-dreissenid mussel studies (Guildford et al. 2005, North et al. 2007) have focused only on the summer stratification period, which could overlook the seasonality of nutrient limitation.

\section{Silica dynamics}

Our results demonstrate the existence of seasonal Silimitation by phytoplankton, despite significant declines in water column P concentrations due to nutrient abatement programs in the watershed. Bioassay experiments and water chemistry data collected from 1960 to 1980 confirmed that Si-limitation occurred by summer 
stratification in Lakes Michigan, Erie, and Ontario (e.g. Barbiero \& Tuchman 2001), during the same period when concentrations of TP were as high as $25 \mathrm{\mu g} \mathrm{l}^{-1}$ in both Lakes Erie and Ontario (Dobson et. al. 1974). However, our study suggests that the occurrence of Silimitation is now restricted to the spring-early stratification period, which may reflect reductions in P concentrations and concomitant relief in Si-depletion (Schelske et al. 1986).

An apparent reversal of the seasonal Si-depletion has been observed in Lake Michigan, as evidenced by a rise in spring soluble $\mathrm{Si}$ concentrations and diatom abundance (Barbiero et al. 2002). Even though P levels were reduced in Lake Michigan between 1961 and 1995, it was not until after 1983 that Barbiero et al. (2002) observed an apparent relaxation in Si-depletion. This was most likely due to the long hydraulic residence time in Lake Michigan ( 191 yr, Johnegen et al. 1994), where internal recycling dictates Si-limitation (Conley et al. 1988). Conversely, Lake Erie has a short hydraulic residence time ( $2.5 \mathrm{yr}$, Beeton et al. 2004), large inflow of Si-rich waters from Lake Huron through the Detroit River (95\% of total inflow into Lake Erie; Schelske \& Stoermer 1971), and a shallow western basin that regenerates $\mathrm{Si}$ from sediments through wind-driven mixing (Schelske \& Stoermer 1971). Thus one might expect the reversal of seasonal Si-depletion to occur much more rapidly in Lake Erie than in Lake Michigan.

Evidence for relief of Si-depletion has been inferred from ambient $\mathrm{Si}$ concentrations both lake-wide (Makarewicz et al. 2000) and within the central basin (Rockwell \& Warren 2003, Guildford et al. 2005) as well as from concurrent shifts in diatoms from eutrophic species to mesotrophic (Makarewicz 1993) and oligotrophic species (Stoermer et al. 1996). Despite the rise in Si levels and shift in diatom species in Lake Erie, ambient Si levels measured here (2002 to 2003) were still well below the $400 \mu \mathrm{g} \mathrm{Si} \mathrm{l}^{-1}$ level, at which diatoms become growth limited (e.g. Schelske et al. 1986). Data reported by Guildford et al. (2005) corroborate this finding; in July 1997, dissolved Si was drawn down to $0.5 \mu \mathrm{mol} \mathrm{l}^{-1}$ in the central basin, a concentration that is potentially limiting for diatom growth (Schelske et al. 1986, Ragueneau et al. 2000). Taken together, these data suggest that Si-limitation has become less pervasive, but is still likely to occur during spring in the central basin of Lake Erie.

\section{Nitrogen dynamics}

Phytoplankton exhibited a growth response to $\mathrm{N}$ enrichment during late summer and fall, which is characteristic of assemblages that are secondarily lim- ited following satisfaction of their primary limiting resource (Tilman 1982). In the Great Lakes, this condition has historically been attributed to P-enrichment in specific areas. For example, bioassays and ambient $\mathrm{N}$ concentration data suggest that secondary limitation occurred in very enriched regions within Lakes Ontario and Erie from the late 1960s to the mid-1970s (Schelske et al. 1978, Murphy 1980). N-limitation was reversed in Lake Erie by 1983, due to P-abatement programs; this reversal was substantiated by bioassay results which indicated that the phytoplankton had once again become primarily growth limited by $\mathrm{P}$ (Hartig \& Wallen 1984).

With this in mind, we suggest a different mechanism for the apparent reappearance of secondary $\mathrm{N}$ limitation in Lake Erie that is likely related to internal nutrient recycling as opposed to the external nutrient loading. Selective feeding by introduced dreissenids can increase the rate of $P$ recycling back into the water column as a byproduct of grazing, and therefore lead to a decrease in water column N:P ratios (Nichols et al. 1999, Vanderploeg et al. 2001). Mesocosm studies have demonstrated that dreissenids decrease water column N:P ratios and promote shifts in phytoplankton species composition toward taxa associated with more N-limited conditions (e.g. Heath et al. 1995).

Along these lines, the ambient N:P molar ratio measured here (2002 to 2003) fell below 32:1 by the end of summer stratification in Lake Erie. Using the Redfield cellular ratio $(16: 1)$ as a transition point to $\mathrm{N}$ limitation (Redfield et al. 1963), these molar ratios fall within the range where N-limitation can occur (Klausmeier et al. 2004). We did not estimate TN concentrations from our samples, so that our N:P calculation was derived from a comparison of dissolved inorganic $\mathrm{N}$ to $\mathrm{TP}_{\text {; }}$ it may therefore have been liberal. Dissolved inorganic N constitutes $\sim 50 \%$ of $\mathrm{TN}$ in the central basin of Lake Erie (see Makarewicz et al. 2000). Nevertheless, we suspect that these values are useful for several reasons. First, dissolved forms of $\mathrm{N}_{\text {, }}$ such as $\mathrm{NO}_{3}-\mathrm{NO}_{2}$, constituted the bulk of TN and are immediately available to the phytoplankton. Second, the turnover of organic $\mathrm{N}$ forms that constitute the other $50 \%$ of $\mathrm{TN}$ function as a sink for $\mathrm{N}$, because dissolved $\mathrm{N}$ is tightly cycled by heterotrophic organisms (Gardner et al. 1987). Third, the majority of TP is associated with living seston, and the turnover of this P pool is high and readily available to phytoplankton, particularly during the periods when we made our comparisons (Lean et al. 1983).

Thus, our observations are consistent with the hypothesis that changes in internal nutrient recycling (via dreissenid mussels) coincide with the occurrence of secondary N-limitation in our bioassay experiments, as well as those conducted by DeBruyn et al. 
(2004). In their experiments, modest P enrichment led to declines in the sestonic N:P molar ratios of plankton in experimental containers. Sestonic C:N molar ratios measured by Guildford et al. (2005) also point to the occurrence of $\mathrm{N}$ deficiency of phytoplankton, although their data exhibit deficiencies between May and August (1997). More recently, a combination of bioassay and deficiency indices has suggested that $\mathrm{N}$ limitation may be mediated by co-limitation by $\mathrm{Fe}$ in Lake Erie (North et al. 2007); while these studies were carried out in the eastern basin, they do coincide with the seasonal patterns (August to September) seen here. However, we do not think that metal co-limitation was a factor in our experiments. Despite the fact that our nutrient stocks were not metal-clean preparations, very small quantities of potentially limiting metals could have been inadvertently added as trace contaminants $\left(<2 \mathrm{nmol} \mathrm{l}^{-1}\right)$ compared to quantities known to illicit a response (Twiss et al. 2000, North et al. 2007).

\section{Biomass yield and nutrient enrichment}

Other studies have shown strong seasonal patterns in the degree of P-limitation in Lake Erie, where Plimitation became more pronounced with the progression of thermal stratification, only subsiding following isothermal mixing in fall (e.g. Lean et al. 1983). Given the factorial design of our experiments, we were able to evaluate the role of individual nutrients $(\mathrm{Si}, \mathrm{N}$, and P), by calculating the biomass yield attributable to individual enrichment with each nutrient (see Fig. 4). The yield of algal biomass achieved from our bioassay experiments revealed that the phytoplankton were least nutrient limited during June (0.8 to $3.4 \mu \mathrm{g}$ chl a $\mathrm{l}^{-1}$ ) and most limited during July (15.2 and $19.8 \mu \mathrm{g} \mathrm{chl} \mathrm{a}$ $\mathrm{l}^{-1}$, Stns 36 and $78 \mathrm{M}$, respectively) and in August (e.g. Stn 43M: $19.4 \mu \mathrm{g} \mathrm{chl} \mathrm{a} \mathrm{l}{ }^{-1}$ ). These results seem reasonable, given that low yields occurred during the spring when ambient nutrients were high; conversely, high yields were achieved in the summer when nutrients were present in low concentrations in Lake Erie (Makarewicz et al. 2000).

Contribution of $\mathrm{Si}_{1} \mathrm{P}$, and $\mathrm{N}$ to biomass yield was clearly distinguished by the 3 thermal periods: spring overturn, summer stratification, and autumn overturn, respectively (Fig. 4). On all dates and at all stations, P enrichment alone produced biomass yields that were 3.6-fold higher than controls, where P-limitation was most important during mid-summer as observed by others (Lean et al. 1983, Guildford et al. 2005). In June, $\mathrm{P}+\mathrm{Si}$ produced algal yields that were 2 -fold higher than controls ( 2 of 3 stations), where Si contributed 63 to $94 \%$ of the total biomass yield at these stations. In
September, $\mathrm{P}+\mathrm{N}$ promoted biomass yields that were 1.6- and 2.3-fold higher over controls (2 of 3 stations), and $\mathrm{N}$ addition alone could account for 48 to $66 \%$ of the yield at these stations. Finally in October, P added with $\mathrm{N}$ produced 2- and 3-fold higher yields at Stns 36 and $78 \mathrm{M}$, respectively. In this case, $\mathrm{N}$ contributed $>65 \%$ of the biomass yield.

Interestingly, ambient chl a values in the epilimnion of Lake Erie were not statistically correlated with ambient $\mathrm{TP}, \mathrm{Si}$, or $\mathrm{N}: \mathrm{P}$ molar ratios, but were significantly correlated with $\mathrm{N}$ concentrations $(\mathrm{r}=0.23, \mathrm{p}=$ $0.003, \mathrm{n}=36$ ). $\mathrm{N}$ concentrations were also correlated with $\mathrm{N}$ biomass yield estimates $(\mathrm{r}=0.39, \mathrm{p}=0.03, \mathrm{n}=$ 12 ), and no other nutrient was correlated with individual nutrient yields or total yield estimates. These findings, taken in combination with our bioassay results, suggest that ambient TP levels might be high enough that other nutrients such as $\mathrm{N}$ and/or $\mathrm{Si}$ are becoming important in determining phytoplankton biomass within the offshore central basin.
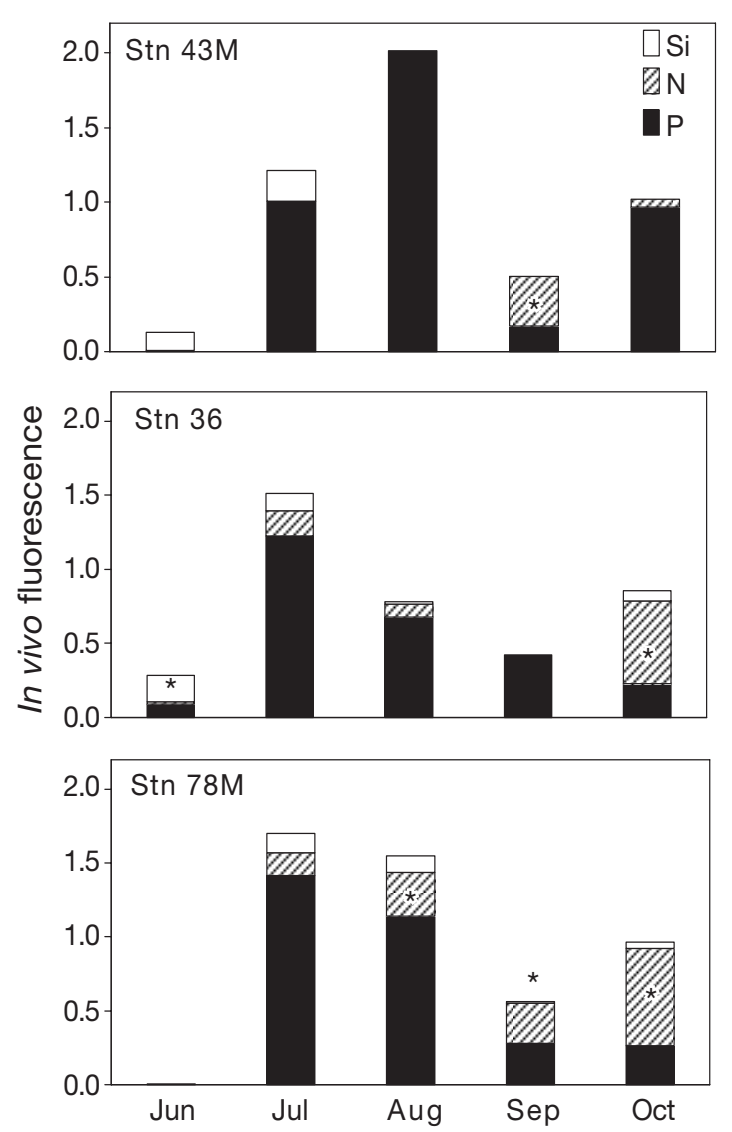

Fig. 4. In vivo fluorescence yield from nutrient enrichment bioassays calculated from $\mathrm{P}, \mathrm{P}+\mathrm{N}, \mathrm{P}+\mathrm{Si}$, and $\mathrm{P}+\mathrm{N}+\mathrm{Si}$ treatments. * $\mathrm{P}+\mathrm{Si}$ or $\mathrm{P}+\mathrm{N}$ treatments that are statistically different $(\mathrm{p}<0.05)$ from $\mathrm{P}$ using 1 -way ANOVA in the in vivo fluorescence analysis 
Acknowledgements. Penn State students Jamie Bosilvecja, Barrett Gaylord, and Casey Godwin provided technical assistance to this project. We thank Glenn Warren and David Rockwell for generously providing water chemistry data, collected during US EPA Lake Erie surveys of 2002 and 2003. We appreciate the assistance provided aboard the RV 'Lake Guardian' and the RV 'Limnos' through EPA and Environment Canada, particularly that of Captain R. Christensen. This research was supported by a grant from the EPA (Great Lakes National Program Office, GLNPO) to H.J.C.

\section{LITERATURE CITED}

Allen CD, Smith REH (2002) The response of planktonic phosphate uptake and turnover to ultraviolet radiation in Lake Erie. Can J Fish Aquat Sci 59:778-786

Arnott DL, Vanni MJ (1996) Nitrogen and phosphorus recycling by the zebra mussel (Dreissena polymorpha) in the western basin of Lake Erie. Can J Fish Aquat Sci 53: 646-659

Barbiero RP, Tuchman ML (2001) Results from the USEPA's biological open water surveillance program of the Laurentian Great Lakes. I. Introduction and phytoplankton results. J Gt Lakes Res 27:134-154

Barbiero RP, Tuchman ML, Warren GJ, Rockwell DC (2002) Evidence of recovery from phosphorus enrichment in Lake Michigan. Can J Fish Aquat Sci 59:1639-1647

Beeton AM (1960) Environmental changes in Lake Erie. Presented at the meeting of the Lake Erie Fish Management Committee, Niagara Falls, Ontario. p 153-160

Beeton AM, Robbins JA, Holland RE (2004) Lake Erie: historical trends and present state. 47th Annu Conf Int Assoc Gt Lakes Res. International Association for Great Lakes Research, Ann Arbor, MI, p 9 (Abstract)

Caron DA (1983) Technique for enumeration of heterotrophic and phototrophic nanoplankton, using epifluorescence microscopy and comparison with other procedures. Appl Environ Microbiol 46:491-498

Carrick HJ (2004) Algal distribution patterns in Lake Erie: implications for oxygen balances in the eastern basin. J Gt Lakes Res 30:133-147

Carrick HJ, Fahnenstiel GL (1989) Biomass, size structure, and composition of phototrophic and heterotrophic nanoflagellate communities in Lakes Huron and Michigan. Can J Fish Aquat Sci 46:1922-1928

Carrick HJ, Schelske CL (1997) Have we overlooked the importance of small phytoplankton in productive waters? Limnol Oceanogr 42:1613-1621

Carrick HJ, Schelske CL, Aldridge FJ, Coveney MF (1993) Assessment of phytoplankton nutrient limitation in productive waters: application of dilution bioassays. Can J Fish Aquat Sci 50:2208-2221

Charlton MN (1999) Lake Erie in transition: the 1990s. In: Munawar M, Edsall T, Munawar IF (eds) State of Lake Erie (SOLE)-past, present, and future. Backhuys, Leiden, p 97-123

Charlton MN (2001) Did zebra mussels clean up Lake Erie? Gt Lakes Res Rev 5:11-15

Conley DJ, Quigley MA, Schelske CL (1988) Silica and phosphorus flux from sediments: importance of internal recycling in Lake Michigan. Can J Fish Aquat Sci 45: 1030-1035

DeBruyn JM, Leigh-Bell JA, McKay RML, Bourbonniere RA, Wilhelm SW (2004) Microbial distribution and the impact of phosphorus on bacterial activity in Lake Erie. J Gt Lakes Res 30:166-183
Dermott R, Munawar M (1993) Invasion of Lake Erie offshore sediments by Dreissena and its ecological implications. Can J Fish Aquat Sci 50: 2298-2304

Dobson HFH, Gilbertson M, Sly PG (1974) A summary of comparison of nutrients and related water quality in Lakes Erie, Ontario, Huron, and Superior. J Fish Res Board Can 31:731-738

Dolan DM (1993) Point source loading of phosphorus into Lake Erie: 1986-1990. J Gt Lakes Res 19:212-223

Dolan DM, Richards RP, McGunagle KP (2004) Analysis of Lake Erie total phosphorus loading for 1996-2003. 47th Annu Conf Int Assoc Gt Lakes Res. International Association for Great Lakes Research, Ann Arbor, MI, p 37 (Abstract)

Dozier BJ, Richerson PJ (1975) An improved membrane filter method for the enumeration of phytoplankton. Verh Int Ver Limnol 19:1524-1529

Elser JJ, Marzolf ER, Goldman CR (1990) Phosphorus and nitrogen limitation of phytoplankton growth in the freshwaters of North America: a review and critique of experimental enrichments. Can J Fish Aquat Sci 47: $1468-1477$

EPA (2003) Sampling and analytical procedures for GLNPO's open lake water quality survey on the Great Lakes. Great Lakes National Program Office US EPA, Chicago, IL, Chpt. 2

Fahnenstiel GL, Chandler JF, Carrick HJ, Scavia D (1989) Photosynthetic characteristics of phytoplankton communities in Lakes Huron and Michigan: P-I parameters and end-products. J Gt Lakes Res 15:394-407

Gardner WS, Chandler JF, Laird GA, Carrick HJ (1987) Sources and fate of dissolved free amino acids in epilimnetic Lake Michigan water. Limnol Oceanogr 32: 1353-1362

GLFC (Great Lakes Fisheries Commission) (1998) Lower trophic level changes and their implications to fish community composition and productivity in Lake Erie. Lake Erie Committee Position Statement, available at www. glfc.org/lakecom/lec/lecpos\%5Ftroph.htm

Guildford SJ, Hecky RE, Smith REH, Taylor WD, Charlton MN, Barlow-Busch L, North RL (2005) Phytoplankton nutrient status in Lake Erie in 1997. J Gt Lakes Res 72 (Suppl 2):72-88

Haltuch MA, Berkman PA, Garton DW (2000) Geographic information system (GIS) analysis of ecosystem invasion: exotic mussels in Lake Erie. Limnol Oceanogr 45: $1778-1787$

Hartig JH, Wallen DG (1984) Seasonal variation of nutrient limitation in western Lake Erie. J Gt Lakes Res 10: 449-460

Heath RT, Fahnenstiel GL, Gardner WS, Cavaletto JF, Hwang SJ (1995) Ecosystem-level effects of zebra mussels (Dreissena polymorpha): an enclosure experiment in Saginaw Bay, Lake Huron. J Gt Lakes Res 21:501-516

Hecky RE, Kilham P (1988) Nutrient limitation of phytoplankton in freshwater and marine environments: a review of recent evidence on the effects of enrichment. Limnol Oceanogr 33:796-822

Hecky RE, Smith REH, Barton DR, Guildford SJ, Taylor WD, Charlton MN, Howell T (2004) The nearshore phosphorus shunt: a consequence of ecosystem engineering by Dreissenids in the Laurentian Great Lakes. Can J Fish Aquat Sci 61:1285-1293

Holland RE (1993) Changes in the planktonic diatoms and water transparency in Hatchery Bay, Bass Island area, western Lake Erie, since the establishment of the zebra mussel. J Gt Lakes Res 19:617-624 
Johengen TH, Johannsson OE, Millard ES (1994) Temporal and seasonal trends in nutrient dynamics and biomass measures in Lakes Michigan and Ontario in response to phosphorus control. Can J Fish Aquat Sci 51:2570-2578

Klausmeier CA, Litchman E, Daufresne T, Levin SA (2004) Optimal nitrogen-to-phosphorus stoichiometry of phytoplankton. Nature 429:171-174

Krammer K, Lange-Bertalot H (1991) Süsswasserflora von Mitteleuropa. Bacillariophyceae. Teil 3: Centrales, Fragilariaceae, Eunotiaceae. Gustav Fischer Verlag, Stuttgart

Laird GA, Scavia D, Fahnenstiel GL, Strong LA, Lang GA (1988) Dynamics of Lake Michigan phytoplankton: relationship to nitrogen and silica fluxes. Can J Fish Aquat Sci 45:1459-1466

Lean DR, Abbott AP, Charlton MN, Rao SS (1983) Seasonal phosphate demand for Lake Erie Plankton. J Gt Lakes Res 9:83-91

Lin CK, Schelske CL (1981) Seasonal variation of potential nutrient limitation to chlorophyll production in southern Lake Huron. Can J Fish Aquat Sci 38:1-9

MacIsaac HJ, Sprules WG, Johannsson OE, Leach JH (1992) Filtering impacts of larval and sessile zebra mussels (Dreissena polymorpha) in western Lake Erie. Oecolgia 92:30-39

Makarewicz JC (1993) Phytoplankton biomass and species composition in Lake Erie, 1970 to 1987. J Gt Lakes Res 19: 256-274

Makarewicz JC, Bertram P (1991) Evidence for the restoration of Lake Erie ecosystem. BioScience 41:216-223

Makarewicz JC, Lewis TW, Bertram P (1999) Phytoplankton composition and biomass in the offshore waters of Lake Erie: pre- and post-Dreissena introduction (1983-1993). J Gt Lakes Res 25:135-148

Makarewicz JC, Bertram P, Lewis TW (2000) Chemistry of the offshore surface waters of Lake Erie: pre- and post-Dreissena introduction (1983-1993). J Gt Lakes Res 26:82-93

Murphy TP (1980) Ammonia and nitrate uptake in the Lower Great Lakes. Can J Fish Aquat Sci 63:141-154

Nalepa TF, Fahnenstiel GL (1995) Dreissena polymorpha in Saginaw Bay, Lake Huron Ecosystem: overview and perspective. J Gt Lakes Res 21:411-416

Nichols KH, Hopkins GJ, Standke SJ (1999) Reduced chlorophyll to phosphorus ratios in near shore Great Lakes waters coincide with the establishment of dreissenid mussels. Can J Fish Aquat Sci 56:153-161

North RL, Guildford SJ, Smith REH, Havens SM, Twiss MR (2007) Evidence for phosphorus, nitrogen, and iron colimitation of phytoplankton communities in lake Erie. Limnol Oceanogr 52:315-328

Patrick R, Reimer CR (1966) Diatoms of the United States, Vol I. Academy of Natural Sciences, Philadelphia, PA

Patrick R, Reimer CR (1975) Diatoms of the United States, Vol II. Academy of Natural Sciences, Philadelphia, PA

Prescott GW (1973) Algae of the western Great Lakes area, 5th edn. W. C. Brown, Dubuque, IA

Ragueneau $\mathrm{O}$, Tréguer $\mathrm{P}$, Leynaert $\mathrm{A}$, Anderson RF and 11 others (2000) A review of the Si cycle in the modern ocean: recent progress and missing gaps in the application of biogenic opal as a paleoproductivity proxy. Global Planet Change 26:317-365

Redfield AC, Fetchum BH, Richards FA (1963) The influence of organisms on the composition of sea-water. In: Hill MN (ed) The sea. Academic Press, New York, p 26-77

Rippka R, Deruelles J, Waterbury JB, Herdman M, Stanier RY (1979) Generic assignments, strain histories and properties of pure cultures of Cyanobacteria. J Gen Microbiol 111:1-61

Editorial responsibility: William Li,

Dartmouth, Nova Scotia, Canada
Rockwell DC, Warren GJ (2003) Lake Erie report for the Great Lakes National Program Office's indicators monitoring program, 1983-2002. 46th Annu Conf Int Assoc Gt Lakes Res. International Association for Great Lakes Research, Ann Arbor, MI, p 70 (Abstract)

Scavia D, Fahnenstiel GL (1987) Dynamics of Lake Michigan phytoplankton: mechanisms controlling epilimnetic communities. J Gt Lakes Res 13:103-120

Schelske CL (1984) In situ and natural phytoplankton assemblage bioassays. Algae as ecological indicators. Academic Press, New York

Schelske CL, Stoermer EF (1971) Eutrophication, silica depletion, and predicted changes in algal quantity in Lake Michigan. Science 173:423-424

Schelske CL, Rothman ED, Simmons MS (1978) Comparison of bioassay procedures for growth-limiting nutrients in the Laurentian Great Lakes. Mitt Int Ver Limnol 21:65-80

Schelske CL, Stoermer EF, Fahnenstiel GL, Haibach M (1986) Phosphorus enrichment, silica utilization, and biogeochemical silica depletion of the Great Lakes. Can J Fish Aquat Sci 43:407-415

Schindler DW (1977) The evolution of phosphorus limitation in lakes. Science 195:260-262

Shoaf WT, Lium BW (1976) Improved extraction of chlorophyll $a$ and $b$ from algae using dimethyl sulfoxide. Limnol Oceanogr 21:926-928

Sterner RW, Elser JJ (2002) Ecological stoichiometry: the biology of elements from molecules to the biosphere. Princeton University Press, Princeton, NJ

Stoermer EF, Emmert G, Julius ML, Schelske CL (1996) Paleolimnologic evidence of rapid recent change in Lake Erie's trophic status. Can J Fish Aquat Sci 53:1451-1458

Strathmann RR (1967) Estimating the organic carbon content of phytoplankton from cell volume or plasma volume. Limnol Oceanogr 12:411-418

Tilman D (1982) Resource competition and community structure. Princeton University Press, Princeton, NJ

Twiss MR, Auclair JC, Charlton MN (2000) An investigation into iron-stimulated phytoplankton productivity in epipelagic Lake Erie during thermal stratification using trace metal techniques. Can J Fish Aquat Sci 57:86-95

Vanderploeg HA, Liebig JR, Carmichael WW, Agy MA, Johengen TH, Fahnenstiel GL, Nalepa TF (2001) Zebra mussel (Dreissena polymorpha) selective filtration promoted toxic Microcystis blooms in Saginaw Bay (Lake Huron) and Lake Erie. Can J Fish Aquat Sci 58:1208-1221

Vanni MJ (1995) Nutrient transport and recycling by consumers in lake food webs: implications for algal communities. In: Polis GA, Winemiller KO (eds) Food webs: integration of patterns and dynamics. Chapman \& Hall, New York, p 81-95

Verity PG, Robertson CY, Tyonzo CR, Andrews MG, Nelson JR, Sieracki ME (1992) Relationship between cell volume and the carbon and nitrogen content of marine photosynthetic nanoplankton. Limnol Oceanogr 37:1434-1446

Vincent WF (1979) Mechanisms of rapid photosynthetic adaptation in natural phytoplankton communities. I. Redistribution of excitation energy between photosystem I and II. J Phycol 15:429-434

Wetzel RG, Likens GE (2000) Limnological analyses, 3rd edn. Springer Verlag, New York

Whitford LA, Schumacher GJ (1973) A manual of the freshwater algae. Sparks Press, Raleigh, NC

Wilhelm SW, DeBruyn JM, Gillor O, Twiss MR and 6 others (2003) Effect of phosphorus amendments on present day plankton communities in pelagic Lake Erie. Aquat Microb Ecol 32:275-285

Submitted: August 8, 2006; Accepted: April 19, 2007

Proofs received from author(s): June 11, 2007 